\title{
Role of College Music Education in Music Cultural Diversity Protection Yu Fang
}

\author{
JingDeZhen University, JingDeZhen, China, 333000
}

\begin{abstract}
Keywords: college music education; music cultural diversity; protective effect; Chinese Library Classification; Chinese Identification Code
\end{abstract}

\begin{abstract}
College music education, the core component in protecting music diversity, promotes the integral development of the subject characteristic of music and the music essence with its rapid development. Further diversified, music culture fits perfectly with the music education.This essay made analyses on the role of college music education in the protection of music diversity and put forward countermeasures preserving the music diversity during the process of teaching to integrate the education and cultural diversity protection together to build a fine atmosphere and a broad development area.
\end{abstract}

\section{Introduction}

Music education is an important carrier of human culture, and bears the mission of cultural development from the early beginning. Diversified culture brings out the diversified development of music.

In the perspective of cultural development, cultural diversity refers to a nation or a country swallows the excellent cultural accomplishments of other nations and countries under the premise of inheriting its own fine traditional culture during the process of practice and social developing, and then develops a humorous cultural atmosphere of a hundred flowers blooming, a hundred schools of thoughts contending on the basis of its own culture supplemented by the other culture.

Music culture, as an important component of cultural development, should also be diversified. Diversified music culture, with the feature of harmony in diversity and coexistence of variety, can develop in digesting and consistent innovating. Therefore, further protection on music culture is inevitable, while college music education plays a crucial role in this process.

College music education is a significant constitution of cultural education in school as well as the important driver of the generating and developing of music cultural diversity since no culture can inherit or develop without education.

Problems do exit in China's college music education such as the traditional and rigid teaching method, emphasizing on the music knowledge wile undervaluing the skill teaching, students are learning music but no the culture and so on, all going against with the protection of music cultural diversity. Thus valuing college music education is the essential condition to protect the educational cultural diversity.

This paper offered practical guidance discussing music cultural protection from the perspective of college music education.

\section{Current situation of college music education}

\subsection{Neglect on the education of traditional music}

Traditional music, one important part of diversified music cultural system, is the foundation of the development of music cultural diversification. China has a long history and colorful music culture. Emphasized by the government and the academic circle, national music culture was excavated and preserved by enormous musicians who then achieve great success.

With the developing trend of globalization and the spring of popular music, however, music cultural ecology develops in an imbalance mode and is on the decay. Catering to the globalization, college music educators turn their focus to popular music teaching, leading to the lack of successors to a number of traditional music categories, songs and genres. 
The traditional Chinese music is on the verge of extinction as musicians of the older generation are gradually passing away, a shame to the music cultural diversity protection.

According to the official statistics, China's traditional troupes reduced from over 4000 in the 80s last century to about 1000 up to 2003. Protection to China's traditional music cultural heritage is of great urgency.

\subsection{The imperfect education systems}

China has the world's biggest education system with more than 200,000 famous college music educators and 400 college music education institutions cultivating music teachers. This kind of college music education plays a significant role in music cultural development. Today's cultural diversification protection from the college is, however, less than satisfactory.

The Ministry of Education issued Art Education Development Planning in China's Schools (2001 - 2010), and in this report, all the colleges and universities were required to offer restrictive and arbitrary elective courses by 2005 as a part of music curriculum. The real condition, however, is known that more than half of China's colleges and universities fail to offer music elective courses or only with related arbitrary ones, leading to the simplicity of student's music learning.

According to related statistics, $90 \%$ of the college students selected popular music, $53 \%$ selected the western vocal music and symphony, and $27 \%$ selected national music, while almost no students made diversified choice. Simplified study made no good for the diversified development of music culture. There remains much to do for the modern college education system in protecting the music cultural diversification.

\subsection{The weak teaching staff}

Surveys on the music teachers of five colleges in Gansu in 2009 revealed the proportional relation between the title distribution and the ages, which presented a conical distribution that big in the ends and small in the middle.

In terms of title, lecturers accounted for $66 \%$, while professors accounted for only $7 \%$ and less than $30 \%$ even with associate professors. In terms of age, teachers of 30-49 occupied $80 \%$, while those of 20-29 and 50-59 occupied 21\%. In terms of degree, while up to $67 \%$ teachers have master degree, none of them have a doctor degree.

Generally speaking, music majors reached the assessment criteria of the undergraduate art education, which requires a proportion over 35\% of full-time teachers with master and doctor degrees. Young teachers are the backbone of the professional music teaching which still calls for more middle-aged teachers and doctorates.

Table 1 distribution of titles and degrees

\begin{tabular}{llllllll}
\hline type & assistants & lecturers & Associate professors & professors & bachelors & masters & doctors \\
\hline number & 3 & 30 & 9 & 3 & 15 & 30 & 0 \\
proportion & $7 \%$ & $66 \%$ & $20 \%$ & $7 \%$ & $33 \%$ & $67 \%$ & $0 \%$ \\
\hline \multicolumn{7}{c}{ Table 2 distribution of teachers' ages } \\
\hline Age group & $21-30$ & $31-40$ & $41-50$ & $51-60$ \\
\hline number & 3 & 27 & 9 & 6 \\
proportion & $7 \%$ & $60 \%$ & $20 \%$ & $2 \%$ \\
\hline
\end{tabular}

\subsection{The lack of emphasize}

College music education has a relatively late start of 1950s, but history stopped its further development until time comes into the 80s with several famous colleges and universities such as Tsinghua, Peking University and Shenyang Aerospace University built music teaching and research sections. 
China's music education, however, depends on the spontaneous actions of some universities and colleges rather than the whole education system. Being not emphasized, the superficial and formalistic music education is nice to have and acts as pretty flowers to some schools.

There were even scholars that pointed out the awkward situation of music education as "important when describing, less important when practicing, and no need to exit when busy". The embarrassment caused the difficulties in college music education's adopting to the diversified development of society. While the further development of China's music education faces more urgent problems to resolve.

\section{The role of college music education in protecting music cultural diversity}

\subsection{College music education is the main driving force of music cultural diversified development}

College music educators bring to scholars complete new music values, namely the ethnic diversity determines the music cultural diversity, different music elements, whether pop music from Europe or campus music from Taiwan, all contribute to China's cultural diversification and the public music life.

Helping people better understand the meaning of music cultural diversification, college music education contribute to the acceptance of the coexistence of music cultural diversity. The positive role of music cultural diversity can then be recognized to reform the teaching planning and the faculty training to accelerate the development of diversified music culture in colleges and university.

Moreover, courses of Western pop music, vocal music and symphony offered by several universities and colleges pushed the diversified development of music culture. College music education, the tie links different music cultures, makes good for deficiency and get a hundred flowers blooming, a hundred schools of thoughts contending.

Colleges are not only the carrier of one single culture, but also the place of socialization with different kinds of social cultural activities taking place like a raging fire. Making good use of it to carry out the learning activities of music cultural diversification would play a certain positive role in protecting music cultural diversity.

\subsection{College music education promotes the educational ideas of music cultural diversity}

\subsection{College music education helps to integrate diversified music culture and attract talents}

Colleges are seen as an aggregation of all kinds of advanced ideas, the birthplace of cultural diversity education accepting different kinds of excellent music cultures. The aim of college music education is to cultivate talents that meet the needs of diversified music development, to improve students' creativity and to help them absorb the excellent diversified music culture.

When concerning the protection of traditional folk music compatible with alien ones, college music education can help find the balance point of consensus, the teaching attitudes and ideas on how the music education going abroad and reaching out to the world. Meanwhile, when reflecting the college music teaching, teachers should constantly interpret the connotation of new music curriculum to ensure that the many kinds of education activities such as teaching researches and teaching ideas spreading are all for the realization of music education targets that help students learn as soon as possible the diversified development mode of music culture.

What can be learned is that music education in schools can better protect the diversified development of music culture in communicating the education ideas of diversified music culture.

Culture develops as a whole and music has no boundaries. Combining different music cultures and integrating political, economic and cultural elements together, college music education makes all the music cultures merging and interacting with each other. Attracting diversified music talents, which can only be realized with the support of college music education, people can correctly understand music cultures experiencing the cultural diversity to create a diversified music culture.

Moreover, all kinds of music cultures can be developed in the college music education which provides convenience to groups and individuals with different music cultural backgrounds coming 
from all sides to integrate with the work of music diversification by communicating and exchanging knowledge and strategies to promote the process.

Therefore, effectively disseminating and drawing lessons from foreign music cultures, college music education can integrate different peoples' music cultures into an organic whole with effective transitions and then promote the cultural development and social progress with the help of powerful music culture flourished by the multiple music talents.

\section{Suggestions on protecting music cultural diversity}

\subsection{Establishing the concept of diversified music cultural education}

In today's diversified music development, China's college music education has played an indispensable role. From the above analyses, several suggestions can be proposed.

College music education in China differs a lot with the Western developed countries. Developing modern talents of all levels is the main task of China's college music education, the teaching mode of which is, however, indiscriminately imitate the Western mode, leading to the over emphasize on the western music while neglecting the national.

Moreover, while focusing on the music, humanistic education was ignored. The unbalance along with the simplified and immobilized instructional thinking mode greatly hindered the development of college music education. The fundamental reason is that universities and colleges in China lack the education theory of diversified music culture.

Therefore, it is essential to build the educational theory of diversified music culture, to innovate the thinking mode of traditional music education, and to emphasize the humanistic education in promoting the coexistence of diversified music culture.

\subsection{Setting up the curriculum of diversified music cultural education}

It is essential to create diversified college music cultural curriculum to better preserve the diversified music culture. Concrete contents of the curriculum should include the essences of music cultures in different nations and the characteristics of diversified music culture.

Attention should be paid to the following points when carrying out the curriculum. First is that the curriculum, expressing the features of diversified music culture, should lead the students to treat or enjoy music cultures whether from their own nation or other nations fairly.

Second is that the development of the curriculum needs a reform to the whole music system. As a complete system, college music education needs to change the education environment and the school education system to implement diversified college music cultural curriculum.

The last thing is that diversified teaching conditions are inevitable as to have overall reform to the planning of required and elective courses, letting students learn from what they constantly see and hear.

\subsection{Strengthening the localization diversified music cultural education}

Different nations have their own implementations in the process of diversified music cultural education due to the results of localization. To develop their own specialties, to face new challenges and the impact of foreign music, China's college music education must realize the integration of the multi foreign music cultures and the national culture by localization. It could be said that the localization in the new century pushes the modernization of college music education.

Complex foreign music culture education contains broad fields such as nations, races, genders, classes and so on. China's college music education, in the perspective of localization, should identify the entry point of reflecting the diversified music cultural ideas of equality, scientificalness and rationality.

\subsection{Improving the quality of music teachers}

The diversified education of music culture is advocated and implemented on the foundation ideology of ethnic equality and national cultural diversification. What we should realize first is, however, the top priority carrying out the education is teachers, who should not only equip with proper educational concepts but also teaching abilities as well as lofty ideals. 
Thus during the implementation of the diversified education, teachers should correctly identity their roles as the combination of subject educational experts and subject specialists. Only with that it is possible to penetrate the diversified education into China's college music education.

What the college music education needs are the top scholars and leading educators who can thoroughly reform the traditional teaching ideas with innovative spirit, pioneering courage and great wisdom to completely eliminate the educational monism and to establish China's educational theories of diversified music culture that in accordance with the international. Then can curriculum system fitting China's diversified college culture be constructed.

The real diversified music cultural education lies on the foundation of absorbing the world's advanced cultures while expressing the characteristics of China's own music education.

\section{References}

[1] Sun Luyi, Gong Zhifang. Communication and Responsibility: Open Universities in China and Community Music Education. International Journal of Community Music . 2011.

[2] Hallam, Susan. Music Education in the 21st Century in the United Kingdom: Achievements, Analysis and Aspirations. . 2010.

[3] Kos, Ronald P. Developing Capacity for Change: A Policy Analysis for the Music Education Profession. Arts Education Policy Review. 2010.

[4] Russell-Bowie, Deirdre. Cross-National Comparisons of Background and Confidence in Visual Arts and Music Education of Pre-service Primary Teachers. . 2010.

[5] Johnson, Vicky V. Competencies, Curricula, and Compliance: An Analysis of Music Theory in Music Education Programs in Texas. . 2010. 